\title{
アルミニウム合金のミグ溶接における被包ガス $(\mathrm{He})$ えの窒素添加についで
}

\section{萬谷泰一郎**・野谷 秀雄 ${ }^{* *}$}

Addition of nitrogen to shield gas $(\mathrm{He})$ in $\mathrm{MIG}$ welding of aluminum alloys

(UDC $669.715: 621.791 .85$ )

MANTANI Taiichiro and NOTANI Hideo

In the previous paper it was reported that grains in bead of MIG welded aluminum alloys were refined and welding cracks were decreased by the addition of nitrogen to argon gas.

However, the welding usability was lowered by the addition of nitrogen; i. e., the stability of arc was made poor and the appearance of bead was made irregular.

In order to avoid the above defects, $\mathrm{He}-\mathrm{N}_{2}$ mixed gas was used for MIG welding of the specimens instead of $\mathrm{Ar}-\mathrm{N}_{2}$ mixed gas.

The following results were obtained.

(1) Arc was made more stable and the appearance of bead was also made better in $\mathrm{He}-\mathrm{N}_{2}$ than in $\mathrm{Ar}-\mathrm{N}_{2}$ gas.

(2) The depth of penetration was increased by the addition of nitrogen.

(3) The grains in bead were refined by $\mathrm{MIG}$ welding in $\mathrm{He}-\mathrm{N}_{2}$ as well as in $\mathrm{Ar}-\mathrm{N}_{2}$ gas, when $\mathrm{Al}-\mathrm{Zn}-\mathrm{Mg}$ alloys containing small amounts of titanium and zirconium (which are powerful elements for grain refining) were used for the parent metal.

(4) Welding cracks were decreased in inert gases containing nitrogen for the welding of $\mathrm{Al}-\mathrm{Zn}-\mathrm{Mg}$ alloys.

(Recieved Sep. 6, 1968)

\section{1. 緒言}

今日，アルミニウム合金の MIG 溶接に使われている 不活性ガスは，JIS に規定されている溶接用高純アルゴ ンであるが，このアルゴンに窒素ガスを添加して使用し た場合, 気孔, 溶込み深さ, 機械的性質に良い影響があ るといわれている。さらに筆者らの一人が行なつた実験 の結果を利用すれば1)， Ti, Zr などを含有するアルミニ ウム合金溶接材を MIG 溶接する場合，窒素を加えたア
ルゴンガスを使えば上記の効果の他に，溶接部の組織が 微細化されるものと考えられ，この点に着目して実験を 行ない，その結果をすでに報告した ${ }^{2)}$ 。また，一般に溶 接部の組織微細化は溶接割れ防止に有効であるといわれ ており，この点についてもじやつかんの検討を加え同時 に述べた。

ところが，アルゴンに窒素を添加した場合，組織の微 細化が起ると同時に溶接割れも減少する傾向にあつて, 一応所期の目的は達成されたものの，一方では溶接アー

Table 1 Ghemical compositions of parent metals and electrode wires.

\begin{tabular}{|c|c|c|c|c|c|c|c|c|c|c|c|}
\hline \multicolumn{2}{|r|}{ alloy } & $\mathrm{Si}$ & $\mathrm{Fe}$ & $\mathrm{Cu}$ & $\mathrm{Mn}$ & $\mathrm{Mg}$ & $\mathrm{Zn}$ & $\mathrm{Cr}$ & $\mathrm{Ti}$ & $\mathrm{Zr}$ & $\mathrm{Al}$ \\
\hline \multirow{3}{*}{ 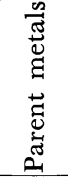 } & $\mathrm{Al}-\mathrm{Zn}-\mathrm{Mg} 1$ & 0.092 & 0.15 & 0.030 & 0.31 & 2.30 & 3.91 & 0.003 & 0.007 & 0.20 & bal. \\
\hline & $\mathrm{Al}-\mathrm{Zn}-\mathrm{Mg} 2$ & 0.072 & 0.17 & 0.022 & 0.44 & 1.10 & 4.45 & 0.21 & 0.075 & 0.093 & bal. \\
\hline & 5083 & 0.085 & 0.18 & 0.049 & 0.51 & 4.77 & 0.023 & 0.19 & 0.006 & - & bal. \\
\hline \multirow{3}{*}{ 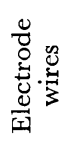 } & $\mathrm{Al}-\mathrm{Zn}-\mathrm{Mg}$ & 0.094 & 0.20 & 0.026 & 0.29 & 2.21 & 4. 10 & 0.002 & 0.004 & 0.180 & bal. \\
\hline & $\mathrm{Al}-\mathrm{Mg}-\mathrm{Zn}$ & 0.082 & 0.16 & 0.007 & 0.46 & 3.95 & 1.56 & 0.25 & 0.053 & 一 & bal. \\
\hline & 5183 & 0.088 & 0.17 & 0.023 & 0.70 & 4.49 & 0.030 & 0.20 & 0.009 & - & bal. \\
\hline
\end{tabular}

* 軽金属学会第34回大会にて発表。

** 近畿車輛株式会社（東大阪市) Kinki Shyaryo, Co., Ltd. (Higashiosaka) 
Table 2 Combinations of parent metals and electrode wires.

\begin{tabular}{|c|c|c|c|}
\hline alloy & & Parent metals & Electrite wires \\
\hline Combination 1 & 1 & $\mathrm{Al}-\mathrm{Zn}-\mathrm{Mg} \mathrm{I}$ & $\mathrm{Al}-\mathrm{Zn}-\mathrm{Mg}$ \\
\hline " & 2 & $\mathrm{Al}-\mathrm{Zn}-\mathrm{Mg} 2$ & $\mathrm{Al}-\mathrm{Mg}-\mathrm{Zn}$ \\
\hline " & 3 & 5083 & 5183 \\
\hline
\end{tabular}

クが不安定になり，電流，電圧を電磁オシロで測定する と，電極線が短絡しており，その部分のビード外観が悪 くなり，いわゆる溶接作業性に悪影響が認められた。

本報告は， $\mathrm{Ar}-\mathrm{N}_{2}$ の代りに $\mathrm{He}-\mathrm{N}_{2}$ ガスを用いて，ま つたく同様の実験を行ない，ヘリウムガスへの窒素添加 による，組織の微細化および溶接割れについて調査する とともに，溶接作業性について検討したものである。

\section{2. 実験方法}

\section{1 試 料}

供試材は母材に 2 種の $\mathrm{Al}-\mathrm{Zn}-\mathrm{Mg}$ 系合金およびAl-Mg 系5083合金を，電極線には $\mathrm{Al}-\mathrm{Zn}-\mathrm{Mg}, \mathrm{Al}-\mathrm{Mg}-\mathrm{Zn}$ 系合 金および5183合金の 3 種類である。これらの化学組成を

Table 1 に示す。また母材と電極線の組合せを Table 2 に示す。

\section{2 実験方法}

溶接は $12 \times 200 \times 125 \mathrm{~mm}$ の板に， $1.6 \mathrm{~mm} \phi$ の電極線を 用いて, $40 \mathrm{~m}$ m間隔で 1 枚の板に 4 本のビード置き溶接 を行なった。溶接条件は全自動 MIG 溶接で, 電流 260 $\mathrm{Amp}$, 電圧 $24 \mathrm{~V}$ ，溶接速度 $500,800,1000 \mathrm{~mm} / \mathrm{min}$ であ る。

ヘリウムと窒素の流量は, ヘリウム単体の場合 $38 l / \mathrm{min}$ 流し，これに窒素ガスを $2.7,5.5,8.0 \mathrm{l} / \mathrm{min}$ 加えた。

以上の条件で溶接したビードについて外観検查を行な マ，この後ビードの中央部を切断して，組織を顕微鏡で 観察した。な抗この試片で溶込み深さも調べた。

溶接割れの試験は， $20 \times 200 \times 125 \mathrm{~mm}$ の板を使つて， 組合せ 2 について，フィスコ割れ試験とすみ肉割れ試験 を行なつた。

なお，溶接電流，電圧および被包ガスの混合割合が $\mathrm{Ar}-\mathrm{N}_{2}$ の場合と多少異つているので，ビード外観の検査 はあらためて $\mathrm{Ar}-\mathrm{N}_{2}$ ガスを使つて溶接したものと比較 した。

\section{3. 実験結果}

\section{1 溶接作業性について}

実際の溶接作業に際して，アークの安定性は作業能率 に大きく影響する。このアークの安定性は溶接機の性能 や溶接条件の良否などによるところが大きいものと思わ
れるが，本実験の場合は窒素ガスを添加することによつ てアークの発生状況が変り, ビード外観が変化する。し たがってここにいら溶接作業性は，ヘリウムに窒素ガス を添加して使用した場合のアークの安定性，つまり短絡 移行やバーンバックの起る程度そしてこれにともなうビ ード外観の良否をとり上げて検討したものである。

Photo. 1 は組合せ 1 を $\mathrm{Ar}^{-} \mathrm{N}_{2}$ 混合ガスを使つて溶接 した場合のビード外観である。窒素を加えると，ビード のところどころが細くくびれているが，これは母材と電 極線が短絡したか，もしくは短絡はしていないがかなり 接近したために，アーク長が短くなり，正常なスプレー 移行が行なわれていないことを示す。これに反して Photo. 2 の $\mathrm{He}-\mathrm{N}_{2}$ の場合は，ヘリウム単体ではビード の波目が相当あらく，むしろ窒素を添加した場合のほう が良いようである。またアークの安定性も $\mathrm{Ar}-\mathrm{N}_{2}$ よりも 良く,短絡はきわめて少なかつた。したがつてビード外観 は写真に見るごとく良好である。Photo. 3 は Photo. 2 と同じ $\mathrm{He}-\mathrm{N}_{2}$ を使つた場合である。(1)は組合せ 2，(2)

(a)

(b)

(c)

(d)

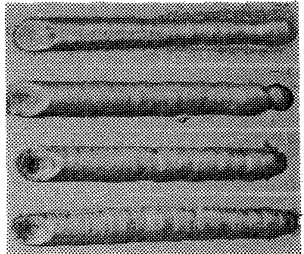

(A)

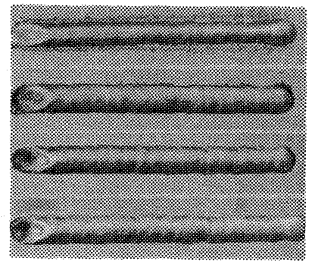

(B)
Photo. 1 Appearance of bead on plate weld specimens. Combination 1. Welding current 260 Amp.; Arc voltage $24 \mathrm{~V}$.

(A): Welding speed $500 \mathrm{~mm} / \mathrm{min}$.

(B): Welding speed $800 \mathrm{~mm} / \mathrm{min}$.

(a): Shield gas Ar $28 \mathrm{l} / \mathrm{min}$.

(b): Shield gas Ar $28-\mathrm{N}_{2} 2 l / \mathrm{min}$.

(c): Shield gas Ar 28- $\mathrm{N}_{2} 4 \mathrm{l} / \mathrm{min}$.

(d): Shield gas Àr $28-\mathrm{N}_{2} 6 i / \mathrm{min}$.

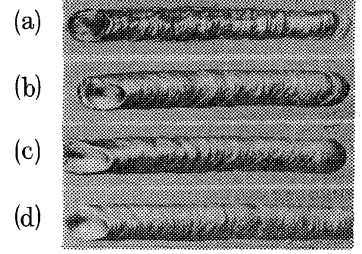

(A)

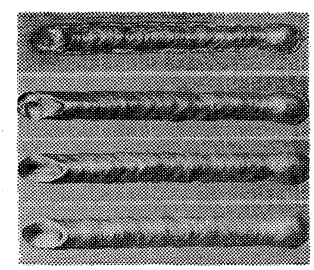

(B)
Photo. 2 Appearance of bead on plate weld specimens. Combination 1. Welding speed are the same as photo. 1 .
(a): Shield gas He $38 \mathrm{l} / \mathrm{min}$.
(b): Shield gas $\mathrm{He} 38-\mathrm{N}_{2} 2.7 \mathrm{l} / \mathrm{min}$.
(c): Shield gas $\mathrm{He} 38-\mathrm{N}_{2} 5.5 \mathrm{l} / \mathrm{min}$.
(d): Shield gas $\mathrm{He} 38-\mathrm{N}_{2} 8.0 \mathrm{l} / \mathrm{min}$. 
(a)

(b)

(c)

(d)

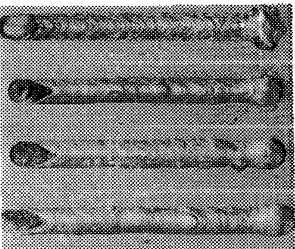

(1)

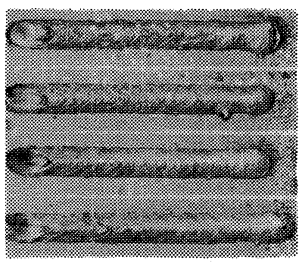

(2)
Photo. 3 Appearance of bead on plate weld specimens. Shield gas are the same as Photo. 2. Welding speed $800 \mathrm{~mm} / \mathrm{min}$.

(1): Combination 2.

(2): Combination 3 .

Table 3 Effects of nitrogen addition to argon and helium on bead appearance. $\bigcirc$ good, $\triangle$ fairly good, $\mathbf{\Delta}$ poor, Oremarkably poor.

\begin{tabular}{|c|c|c|c|c|c|c|c|c|c|c|c|}
\hline \multirow{2}{*}{\multicolumn{3}{|c|}{$\begin{array}{c}\text { Shield gas } \\
(1 / \mathrm{min})\end{array}$}} & \multirow{2}{*}{\multicolumn{3}{|c|}{$\begin{array}{c}\text { Combination } 1 \\
\begin{array}{c}\text { Welding speed } \\
(\mathrm{mm} / \mathrm{min})\end{array}\end{array}$}} & \multirow{2}{*}{\multicolumn{3}{|c|}{\begin{tabular}{|c|} 
Combination 2 \\
$\begin{array}{c}\text { Welding speed } \\
(\mathrm{mm} / \mathrm{min})\end{array}$
\end{tabular}}} & \multirow{2}{*}{\multicolumn{3}{|c|}{ 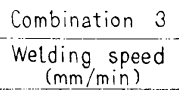 }} \\
\hline & & & & & & & & & & & \\
\hline $\mathrm{Ar}$ & $\mathrm{He}$ & $\mathrm{N}_{2}$ & 500 & 800 & 1,000 & 500 & 800 & 1,000 & 500 & 800 & 1,000 \\
\hline 28 & _ & 0 & 0 & 0 & 0 & 0 & 0 & 0 & 0 & 0 & 0 \\
\hline 28 & - & 2 & $\Delta$ & $\Delta$ & $\Delta$ & & $\mathbf{\Delta}$ & 0 & $\mathbf{A}$ & - & $\bullet$ \\
\hline 28 & - & 4 & $\Delta$ & $\Delta$ & $\Delta$ & $\Delta$ & - & $\Delta$ & $\Delta$ & $\bullet$ & - \\
\hline 28 & - & 6 & $\Delta$ & $\Delta$ & $\Delta$ & 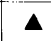 & $\Delta$ & $\Delta$ & $\Delta$ & $\Delta$ & 0 \\
\hline- & 38 & 0 & $\triangle$ & $\triangle$ & 0 & 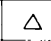 & 0 & 0 & 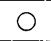 & 0 & 0 \\
\hline- & 38 & 2.7 & 0 & $\Delta$ & $\Delta$ & $\triangle$ & $\triangle$ & 0 & $\Delta$ & 0 & $\boldsymbol{\Delta}$ \\
\hline- & 38 & 5.5 & 0 & $\Delta$ & $\Delta$ & 0 & 0 & 0 & $\triangle$ & 0 & $\Delta$ \\
\hline-1 & 38 & 8.0 & 0 & 0 & $\Delta$ & $\Delta$ & 0 & 0 & $\Delta$ & $\triangle$ & 0 \\
\hline
\end{tabular}

は同じく 3 である。両者ともビード外観は良好である。

これらの外観を純アルゴンで溶接した場合を基準にし て，その良否を判定してまとめたものを Table 3 に示し た。この表から， $\mathrm{Ar}-\mathrm{N}_{2}$ の場合はほとんどが悪いか，も しくはきわめて悪いかであるのに対して， $\mathrm{He}-\mathrm{N}_{2}$ では15 \%が亜いであつて, きわ內て亜いというビードはまつた くない。なお, ○印で表したもののビードは短絡移行を 起した部分が多いために極端に悪いものであり, 溶接継 手として適当でない。しかし， $\mathbf{A}$ 印は Photo. 1 に見ら れる程度のものであつて, 実際の溶接時には特に問題に ならないであろら。

溶込み深さは, 窒素添加によつてじやつかん深くなる が，窒素添加量が多くなつてもそれに比例して増すこと はない。

\section{2 結晶粒について}

Photo. 4 はそれぞれの組合せについて, 溶着金属の粒 状晶組織を示したものである。(a)- 1 はヘリウム単体の 場合であり，(a)-2 は窒素を加えた場合である。結晶粒 は窒素の添加によつて著しく微細化されている。(b)の組 合せ 2 の場合も細かくなつていることが判る。(c)の場合 は，窒素を加えても結晶粒は微細になつていないが，こ れは $\mathrm{Ti}, \mathrm{Zr}$ の含有量がきわめて少ないためであろう。
Photo. 5 は Photo. 4 (a)- 1， 2 と同じ試片の柱状晶組織 であ吕。やはり, 粒状晶と同様窒素添加で微細化してい る。

\section{3 溶接割れについて}

アルミニウム合金の溶接割れは, 溶着金属が凝固する 途中において発生する高温割れが多く，本実験はこの高 温割れのうち，肉眼で見えるものについて調べた。

Fig. 1 (a)は組合せ 2 について，I 型開先, 間隔 $2 \mathrm{~mm}$ ， 狭み板使用で行なつたフィスコ割れ試験の結果である。 この四から窒素添加が割れ防止にかなりの効果を示すこ とが判る。すなわち, 窒素無添加の時のビード割れ率 （クレータ割れを除く）は, 溶接速度 $800 \mathrm{~mm} / \mathrm{min}$ で 7 $\%, 1000 \mathrm{~mm} / \mathrm{min}$ で56\%であるが，窒素 $5.5 \mathrm{l} / \mathrm{min}$ の添 加では，それぞれ0.6\%に減少した。Fig.1(b) はすみ肉 割れ試験の結果である。やはり，窒素添加によつて割れ は減少している。Photo. 6 はフィスコ割れ試験片の外 観の一例である。(a)は窒素を添加しない場合のものであ り，3 本とも割れが発生していて，割れ率100\%である。 (a) -1

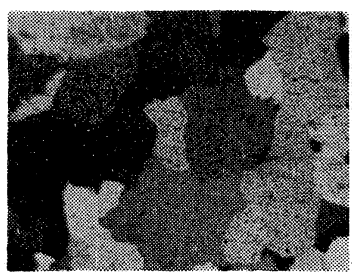

(b) -1 (a) -2

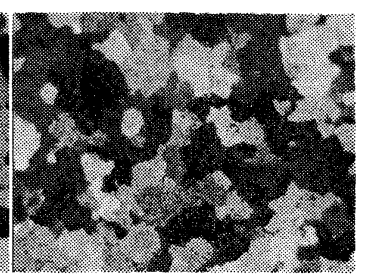

(b) -2

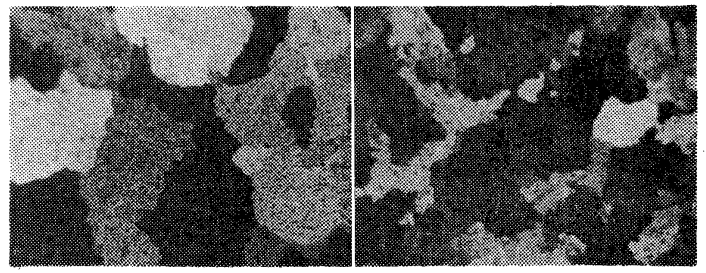

(c) -1

(c) -2

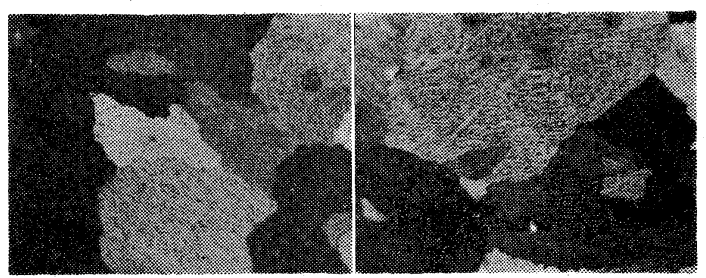

Photo. 4 Granular structure of deposited metal. $(\times 100)$

(a), (b), (c)-1: Shield gas He $38 \mathrm{l} / \mathrm{min}$.

(a), (b), (c)-2: Shield gas He $38-\mathrm{N}_{2} 5.5 \mathrm{l} / \mathrm{min}$.

(a)-1, 2: Combination 1 .

(b)-1, 2: Combination 2 .

(c)-1, 2: Combination 3 . 
このようなことは実験中時折起きた。(b)は窒素を添加し たもので，溶接開始端からわずかに割れているビードが ある。なお Fig. 1 に示す值は同一条件で 5 回試験した 平均である。

\section{4. 考察}

アルミニウム合金の MIG 溶接において，被包ガスに $\mathrm{Ar}-\mathrm{N}_{2} \quad \mathrm{He}-\mathrm{N}_{2}$ 混合ガスを用いた場合のアークの発生状 態には両者間にじやつかんの相異が観察され，また溶接 後のビード外観にも異いが認められた。これらの結果か ら以下にじやつかんの検討を行ないたい。

一般に，被包ガスとしてのアルゴンはアーク柱の冷却 (a) -1

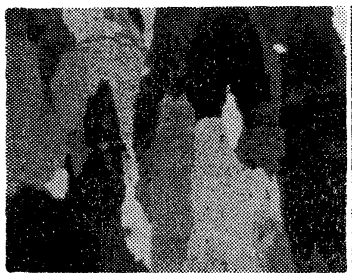

(a) -2

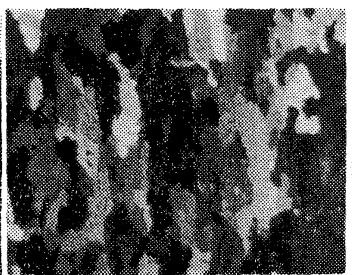

Photo. 5 Columnar structure of deposited metal. $(\times 100)$ Combination 1 .

(a)-1: Shield gas He $38 l / \mathrm{min}$.

(a)-2: Shield gas $\mathrm{He} 38-\mathrm{N}_{2} 5.5 \mathrm{l} / \mathrm{min}$.

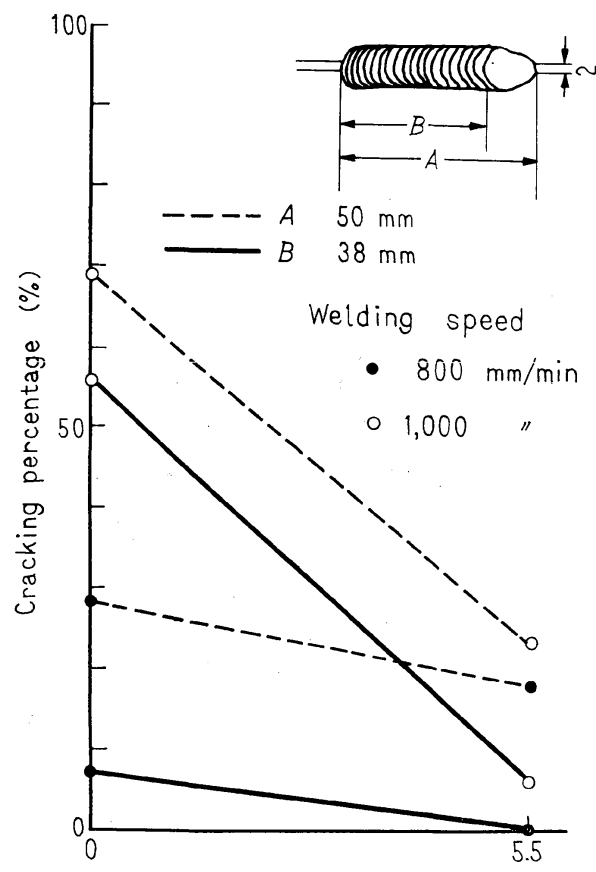

Nitrogen content $(l / \mathrm{min})$

(a) FISCO cracking test
作用が小さく，その電位傾度が小さいために，テークの 発生は電極線端に集中することはない。したがつて溶滴 の離脱は容易であり，小粒子になりやすいといわれてい る334。 ところが，これに窒素ガスを加えれば， $\mathrm{N}_{2} \rightarrow 2 \mathrm{~N}$ なる熱解離のため，アーク柱が冷却され，その断面は収 縮し，アークは電極線端は集中して発生するようになる ものと思われる。このようになつた場合，アルゴン単体 の場合から考えて, 溶滴の離脱は困難となり, 小粒子化 し難くなるものと思われる。Photo. 7 は同一電流, 電 圧に持ける，アルゴンと $\mathrm{Ar}-\mathrm{N}_{2}$ のアークの発生状況で ある。写真から推定するに, $\mathrm{Ar}-\mathrm{N}_{2}$ の場合のアークは母 材溶融池に深くもぐつて発生しているようであり，スパ ツタリングも多いようである。溶接中の肉眼観察でも， 溶融池が深く, ワイヤの突き出し長さが増加していた。 またスパッタ粒も大粒のものが発生した。これらの原因 は，アークが集中して発生したためにプラズマ気流が強 く作用して溶融池が深く堀り下げられ，アーク長の自己

(a)

(b)

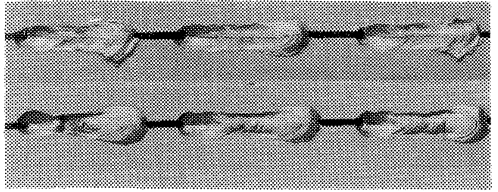

Photo. 6 Appearance of FISCO cracking test specimen. Combination 2. Welding current 280 Amp.; Arc voltage 27 V.; Welding speed 1000 $\mathrm{mm} / \mathrm{min}$.

(a): Shield gas He $38 \mathrm{l} / \mathrm{min}$.

(b): Shield gas $\mathrm{He} 38-\mathrm{N}_{2} l / \mathrm{min}$.

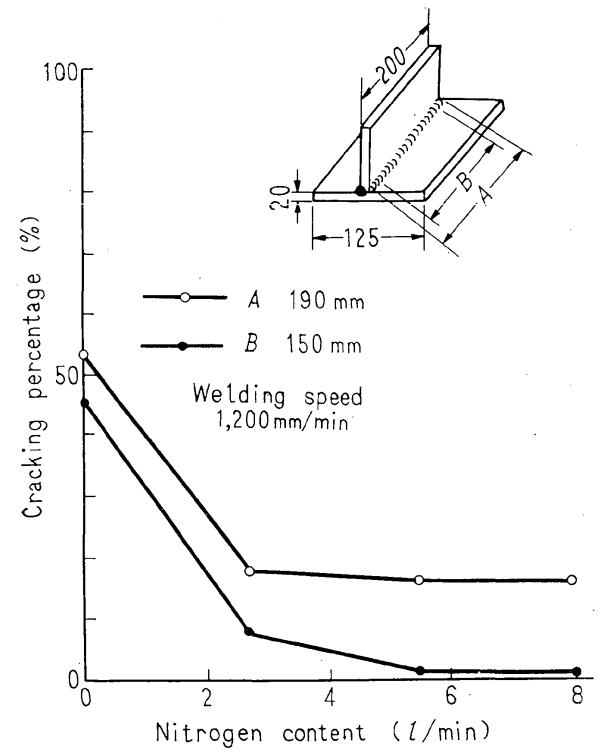

(b) Fillet weld cracking test

Fig. 1 Effects of nitrogen addition to helium on welding crack current 280 Amp. Voltage 27 Volt. 


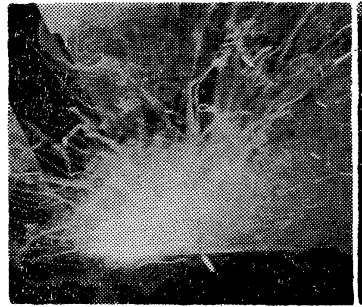

(a) $\mathrm{Ar}$

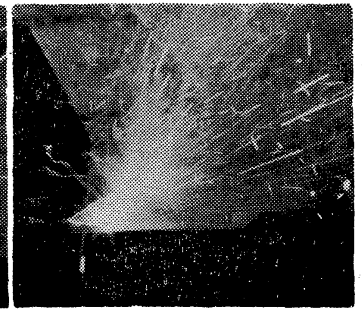

(b) $\mathrm{Ar}-\mathrm{N}_{2}$
Photo. 7 Effect of shield gas on welding arc.

制御作用が働いたからであろう。また溶滴が小粒子とし て離脱し難く, 大粒の状態で移行していることに起因し ているものと考えられる。アークがこのような状態で発 生していると，電極線と母材とが短絡する機会は当然多 くなることが予想される。もし短絡が起きれば，ピンチ 作用によつて短絡は破れ，アークは再生するが，この瞬 間には高温の発生にともなつて, アーク柱は膨脹し，溶 融池を圧迫するといわれている4)。溶接中時々高い音を 発し，この時のビードにはくびれやシワが，時には穴が できており, この瞬間に短絡, そしてアークの再生が起 つたものと思われる。

一方へリウムに窒素を添加した場合, 電位傾度から考 えれば，ヘリウムは窒素よりも電位傾度が大きいため, アーク柱の冷却作用は特に大きくなることはないものと 考えられ，溶滴の離脱は阻害されないものと思われる。 事実ビードの波目はへリウム単体の場合よりも細かくな つており，むしろ小粒子化が促進されている感がある。 しかしながら，アークの発生状況は $\mathrm{Ar}-\mathrm{N}_{2}$ の場合と類 似して抢り，多少溶融池のくぼみは浅くなつていたよう であつたが，やはりへリウム単体の時に比べればアーク はもぐつて発生しており，時偶高い音を発した。ただ， その回数は $\mathrm{Ar}-\mathrm{N}_{2}$ に比較してかなり少なかつた。した がつて， $\mathrm{Ar}-\mathrm{N}_{2}$ および $\mathrm{He}-\mathrm{N}_{2}$ 混合ガスを用いた場合の アーク現象は電位傾度のみで単純に説明することはでき ず，詳細は今後の研究を待ちたい。

つぎに, 窒素を添加した時の溶接部の結晶粒は Photo.
4 亿示すごとく組合せ 1，2 の場合は細かくなつており， また溶接割れは Fig. 1 のように減少している。一般に， 溶接部の結晶粒は細粒の方が割れ発生は少ないとされて いる。これは通常, 細粓の方が凝固時の収縮応力が分散 されやすいこと抢よび㠜固過程に扔いて発生する柱状晶 の接触が始まる温度が細粒ではより低温度側になつて， 脆性範囲が狭くなることによるといわれている5)。筆者 らは, 液膜段階での固相の mass feeding が細粒ほど容 易であり，この結果割れの形成が少なくなるものと考え ている。

\section{5. 結言}

本実験の結果を要約するとつぎのごとくである。

1）アークの安定性は $\mathrm{Ar}-\mathrm{N}_{2}$ の場合よりもかなり良 好であつて，電極線と母材の短絡はまれであつた。した がつてビード外観は良好であつた。

2）ビードの波目はへリウム単体の場合よりも密で女 つた。

3）溶込み深さは, 少量の窒素添加によつてじやつか 儿増す。そして窒素添加量が多くなつてもそれ以上比例 して增すことはない。

4）溶接部の組織は，Zr あるいは Ti が含有している 組合せ 1,2 の場合, 窒素添加によって著しく微細化し た。

5）溶接割れは， $\mathrm{Ti}, \mathrm{Zr}$ を含む母材を $\mathrm{Ti}$ 足含む電極 線で溶接した組合せ 2 の場合，窒素を添加することによ つてかなり減少した。

\section{参 考 文 献}

1）西村, 高瀬, 萬谷, 大阪侍立工業奖励館報告, 32 (1964) 23，32（1964） 27.

2）萬谷，野谷，軽金属，18（1968）282.

3） 安藤，西口，溶接学会誌，36（1967） 1218.

4）安藤, 長谷川, 溶接アーク現象, (1962).

5）·松田，溶接学会誌，36（1967）973. 